\title{
ACTION RESEARCH AND EDUCATIONAL TECHNOLOGY: CULTIVATING DISRUPTIVE LEARNING
}

\author{
F. Waghid \\ Centre for Innovative Education Technology \\ Cape Peninsula University of Technology \\ Cape Town, South Africa \\ e-mail: faiq@live.co.za
}

\section{ABSTRACT}

Nowadays, teaching and learning in South African university classrooms seem to be most prominently spoken of in relation to transformation. In this article, I argue as to why action research offers a pedagogical approach to enhance transformative (disruptive) learning in university classrooms. Firstly, I give an account of action research and how it came to manifest in university education. Secondly, I show as to how educational technology can be used to enhance disruption within pedagogical encounters. And, thirdly, in relation to democratic educational theory I show as to how, using Jacques Ranciere's ideas of disruption and coming to speech can enhance learning through action research.

Keywords: action research, educational technology

\section{INTRODUCTION: ACTION RESEARCH AND UNIVERSITY EDUCATION}

Since the early part of the $20^{\text {th }}$ century, action research has been concerned with three interrelated aspects: the development of educational research aimed at solving social problems, in the work of Moreno, Collier and Lewin in the 1940s to 1960s; the cultivation of selfdevelopment, which involved careful reflection on the individual and collaborative practices of people, informed mostly through the work of Stenhouse, Elliot, Kemmis and McTaggart and Carr and Kemmis in the 1970s and 1980s; and, the enhancement of teaching as a profession through the recognition that educators are knowledge producing with voice who can enact critical change in all educational contexts, as propounded in the work of Cochran-Smith, Goswami and Lytle in the 1990s (Noffke 2009, 8-10). Figure 1 represents some of the key reasons as to why action research originally emerged as an approach to doing social research.

To begin with, firstly, action research as an approach to solve societal problems can be traced back to the work of Kurt Lewin (an American psychologist) who, in the 1940s, explained action research as "proceeding in a spiral of steps, each of which is composed of planning, action and the evaluation of the result of action” (Kemmis and McTaggert 1990, 8). Lewin’s 


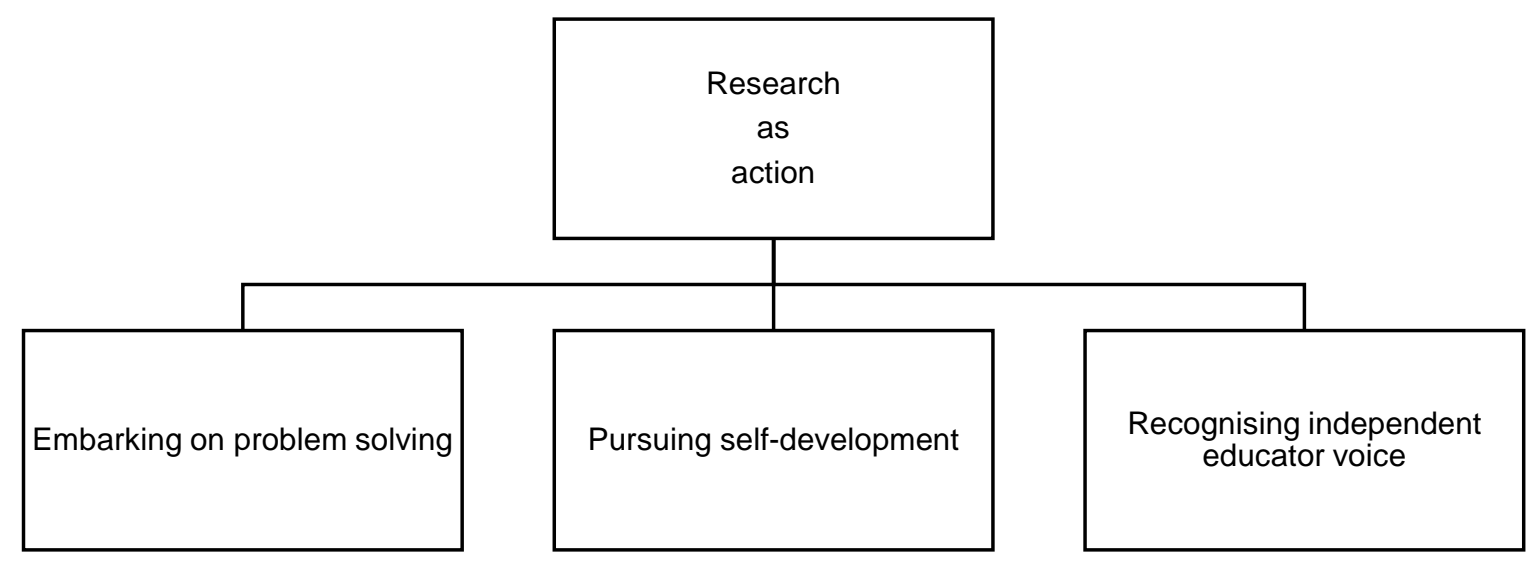

Figure 1: Justification for Social Action Research

position on action research points towards understanding and changing and/or solving societal practices through phases of inquiry (McKernan 1991, 11). Lewin attempted to resolve some societal problems through experimental inquiry comprising action cycles of analysis, fact finding, conceptualisation, planning, implementation and evaluation of action (McKernan 1991, 9). Subsequently, in the 1950s and 1960s, action research was used in the study of industry (McKernan 1991, 10).

Secondly, action research aimed at the self-development of people "depends not on any particular methodological standpoint but rather on a commitment to creating space for a community of inquirers to engage in a good conversation with each other about how best to express their educational values in action” (Elliott 2009, 37). What I deduce from this position of Elliot is that enhancing one's self-development depends on how one engages with others and how to find solutions to university classroom problems through our shared understandings. In a way, self-development through action has a dual function: for educators to reason practically (phronesis) about issues in the classroom; and for educators to change their classroom practices to something better or something more worthwhile (Elliott 2009, 36).

Thirdly, action research as a "stance on practice" (Cochran-Smith, Goswami and Lytle 2009, 47) offers educators a compelling framework within which to enact change that is grounded in the everyday politics of classroom practices. This is so because educators are afforded a "voice" that enables them to interrogate and enact inventive pedagogies that address the real learning needs of students (Cochran-Smith, Goswami and Lytle 2009, 47). By affirming their "voice”, educators develop the distinct potential for rethinking, resisting and reforming 
the ways they think about and take action in classrooms (Cochran-Smith, Goswami and Lytle 2009, 39). The narratives educators produce through systematic reflections on teaching and learning "contain knowledge within them" because the "self" cannot be separated from the action educators embark on (Cochran-Smith, Goswami and Lytle 2009, 40).

What follows from the aforementioned historical moments in the ways that action research effects change in classroom practices is that doing action research cannot happen without invoking the idea of problem solving, pursuing self-development, and affirming one's voice as an educator in classrooms. In the following section I shall draw on the work of McNiff and Whitehead (2006) as an extension of the pioneering work that has already been done in the field, particularly showing how action research can play an important role in higher education contexts.

Action research as a way to solve societal problems relates primarily to improving social contexts (McNiff and Whitehead 2006, 36). McNiff and Whitehead (2006, 36) suggest that there are three social purposes for conducting action research: improving practices through improving learning; promoting ongoing democratic evaluation of learning and practices; and creating good social orders by influencing the education of social formations. It may be reasoned, that as educators working in higher education contexts, all three of the aforementioned aspects should manifest.

About improving practices through improving learning, it can be said that such actions do not happen spontaneously and require some form of systematic approach (McNiff and Whitehead 2006, 37). This involves reflection on the part of individuals on what needs to be done differently in relation to others (McNiff and Whitehead 2006, 37). Individuals then produce an explanatory account of the processes they undertook and make it public (McNiff and Whitehead 2006, 37). This means, that practitioners produce a respectable body of theory that clarifies what is involved in understanding work as a living practice (McNiff and Whitehead 2006, 37). As university educators, we need to reflect on what constitutes good teaching and learning and be amenable to adapt to these practices as our own. This improvement may pertain to enhancing classroom practices through the use of educational technology, and to explore how it can enhance disruption in pedagogical encounters.

In relation to societal problems, researcher-practitioners evaluate their work by promoting an ongoing democratic evaluation of learning and practices in relation to their own values, and do not always require external evaluation (McNiff and Whitehead 2006, 39). Although researcher-practitioners are at all times conscious of the need for stringent testing and evaluation when research is conducted (McNiff and Whitehead 2006, 39), they seem to retain a measure of honesty and the capacity to listen and act on critical feedback (McNiff and 
Whitehead 2006, 38). This willingness to listen may be seen as an important dynamic that enables action research to solve societal problems. The critical insights and judgements of others can allow one to improve one's own teaching practices and the learning of others. Action research manifesting within university contexts has therefore ensured that higher education institutions remains spaces for the creation of communities of inquiry, enabling individuals the capacity to and act on critical feedback. In addition, by creating good social orders through influencing the education of social formations, researcher-practitioners can constitute their own social orders and, in turn, learn to amend their philosophy in order to improve their practices. McNiff and Whitehead (2006, 39) suggest that, when individuals think for themselves and hold themselves accountable for their educational influence, they can contribute towards creating good societies.

Action research towards self-development encompasses the exercise of educational influence to improve practice (McNiff and Whitehead 2009, 69). McNiff and Whitehead (2006, 65) suggest that, for a practitioner-researcher, the goal of research is to improve learning so as to improve practice. The process by which this achievement is attained is then conveyed to all stakeholders involved. This improvement is not imposed, but rather exercised through influence to promote improved change (McNiff and Whitehead 2009, 62). As Elliot (2009, 36) suggests, enhancing one's self-development depends on how one engages with others, therefore engaging in a manner that encourages individuals to change from within rather than having change imposed on them may be seen as a means to improve practice, and consequently selfdevelopment. Influence may have far-reaching implications for the practitioner-researcher and the individuals with which they engage. Action research within a university context, may therefore, foster the self-development, and the capacity of others to think independently about influences they may encounter in order to progress their own thinking.

Thus far, I have shown that action research in the main is framed by at least three considerations, namely embarking on problem solving; pursuing self-development; and taking an independent stance (or asserting your voice). McNiff and Whitehead (2009, 12) confirm and extend the aforementioned views on action research by stating that the latter involves finding new ways to improve learning so that one can improve personal and social circumstances. In other words, problem solving can be extended beyond classroom practices, such as making students aware of and encouraging them to do something about changing societal problems. Furthermore, these authors claim that action research involves rigorous processes of observation (watching what is going on), reflection (thinking about whether it is good and why, and how it can be improved if necessary), monitoring and data gathering (keeping track of what you do and others do). It involves “testing your provisional claims to knowledge” (asking other 
people to look at your work, listen while you explain why you think it is good, and giving you feedback about whether you need to rethink some aspects): "In this way you have created new knowledge of your practice, and you can explain the significance of your research for the new learning and growth of yourself and other people” (McNiff and Whitehead 2009, 12). The manifestation of action research, as a research methodology, can therefore be seen as a contributing factor towards universities reaffirming their positions, as institutions wherein knowledge is collectively constructed.

\section{EDUCATIONAL TECHNOLOGY TO ENHANCE DISRUPTION WITHIN PEDAGOGICAL ENCOUNTERS}

In the contemporary era, it is hoped that education incorporating Information Communication Technologies (ICTs) will encourage flexibility of mind, a creative spirit and a network of contact to ensure sustainability in a competitive world (McHaney 2011, xiii). Not all technology may be effective in the pursuit of this endeavour (McHaney 2011, xiii). McHaney (2011, xvii) calls current students “millennials”. These students are not necessarily smarter or superior, but do have different expectations of the world to students of past generations (McHaney 2011, xvii). These students or "millennials" are distinguishable from other generations in that they have incorporated social media and other forms of communication technology into their everyday lives. They have also been endowed the capability to customise their social media experience, and are able to commoditise, filter and synthesise information (McHaney 2011, xvii). On the downside, these individuals may have little regard for online privacy, have developed a social order on the web and may engage in inappropriate activities on the web (McHaney 2011, xvii).

Despite this downside, their engagement with the web holds much promise in the sense that technology can help to produce a fuller pedagogical experience for students (McHaney 2011, xviii). Working towards a fuller pedagogical experience has been aided by the advent of many social computing, social media smartphone device applications to promote such an experience for students (McHaney 2011, xviii). Various forms of technology thus have converged with one another. The convergence of technology is known as Web 2.0, which consists of five components, namely social computing, social media, content sharing, filtering and web applications (McHaney 2011, xviii). These technologies, which are linked to free information sources, have reshaped the ways in which individuals filter, sort and find relevant information, resulting in new possibilities for learning. Students inherently expect learning material on platforms of their own choice (McHaney 2011, xviii). McHaney (2011, xviii) suggests that when these components are integrated into classroom practices, there is a potential 
for richer knowledge delivery to the millennials that we encounter in classrooms today. Moreover, Garrison and Anderson (2003, 42) posit that educational technology can contribute to democratising classroom pedagogy in the following ways: by keeping an educational group of students synchronised or acting together; by developing connections between students' existing mental schema and new content, information and skills acquired; by guiding the way students interact with one another; and by making it possible for students to follow individual interests and interactive paths.

In fact, what has been discussed this far in relation to educational technology is that technology can facilitate learning on-line, such as through Learning Management Systems (LMS) that is, a form of e-learning that makes it possible to transform teaching and learning in classrooms. In this regard, Garrison and Anderson (2003, xiii) hold that the use of educational technologies can create asynchronous communities of inquiry which have the potential to support the development of communities of learning, while still allowing anytime-anywhere access by students'. In this way, educational technology can engender what Garrison and Anderson (2003, xi) refer to as "explosive, unprecedented, amazing and disruptive” pedagogical opportunities for both students and educators.

\section{DISRUPTION AND COMING TO SPEECH WITHIN PEDAGOGICAL ENCOUNTERS: ENHANCING LEARNING THROUGH ACTION RESEARCH}

Since the mid-1990s it has also not been uncommon to connect Deleuzian thinking with the boom of the Internet, more specifically the use of educational technology (Sutton 2008, 27). Gilles Deleuze, a French philosopher, was born in Paris on 18 January 1925 and studied philosophy at the Sorbonne from 1944 onwards. In 1968, he was appointed to the Université de Vincennes (from which he retired eventually in 1987) and, during the same year, he met Felix Guittari, a Marxist psychoanalyst with whom he co-authored and published A Thousand Plateaus: Capitalism and Schizophrenia in 1980 (translated by Brian Mussumi in 1987; Morss 2000, 187). In the foreword to A Thousand Plateaus, a Deleuzo-Guittarian notion of a plateau is described as follows: “[A] plateau [orchestration of crashing conceptual bricks] is reached when circumstances combine to bring an activity to a pitch of intensity that is not automatically dissipated in a climax" (Deleuze and Guittari 1987, xiv). In other words, a plateau is a metaphor used to describe an intensive state of thought that can be reactivated or injected into other activities. And, progressing from one plateau at a particular level to other plateaus at alternate levels is not linear (or in a straight line), but rhizomatic (Morss 2000, 193). For Deleuze and Guittari $(1987,16)$, thinking that is firmly rooted or anchored in foundational thought (that is disciplinary, reasoned and communicative thought) is "arborescent” or hierarchical in the sense 
that one receives information from a hierarchical superior. For instance, subordinate students receive pre-digested information from educators “along preestablished paths”, and students and educators “can never get beyond” what they have acquired (Deleuze and Guittari 1987, 16). In such a unidirectional relationship between an educator and students, both the educator and the students cannot think beyond the information transmitted between the two parties. In other words, the interpretations and exchanges between the educator and students are fixed along a linear and regulated path determined by what is being said and heard.

Rhizomatic thinking, on the contrary, is different from linear, unidirectional thinking. According to Deleuze and Guittari (1987, 7), "the rhizome itself assumes very diverse forms, from ramified surface extension in all directions to concretion into bulbs and tubers ... the rhizome includes the best and the worst: potato and couchgrass, or the weed”. The rhizome, “[a subterranean root-like stem] lies upon or slightly under the surface, ready to produce a vertical stem when the opportunity arises” (Morss 2000, 193). Thus, rhizomatic thinking involves a form of communication that builds up a network of interconnections with no central organisation. Understanding thinking as rhizomatic involves mapping the paths of meaning or lines of flight [new shoots and rootlets] that people take to forge linkages (Honan 2004, 269). As Alvermann $(2000,118)$ explains, rhizomatic thinking is about "looking for middles, rather than beginnings and endings, [which] makes it possible to decenter key linkages and find new ones, not by combining old ones in new ways, but by remaining open to the proliferation of ruptures and discontinuities that in turn create other linkages”. Thus, rhizomatic thinking, through "starting anywhere", looks for middles and disrupts the taken-for-granted understanding of linear thinking. Students and educators who are thinking rhizomatically are “constantly open to new connections and alternative possibilities” (Le Grange 2011, 748). They (educators and students) would map out new possibilities ("vectors of escape") as they endeavour to move beyond the confines of linear exchanges of information. In this way, critical thinking can be considered as rhizomatic.

In other words, students and lecturers ascertain "lines of flight” or deterritorialisations that rupture the striated or ordered ways of teaching and learning. Failing to create new possibilities for thinking and doing through experimentation would intensify hierarchical relations these teaching and learning spaces. This would in turn mitigate the democratic potential of educational technologies. Thus, it is not a question of equating educational technologies with the rhizome, but of thinking rhizomatically through the use of educational technologies (Conley 2009, 34). Therefore, the emergence of many educational technologies did not occur during the lifetime of Deleuze and Guittari, but they were prescient that these new technologies would contribute to the formation of "assemblages" of learning, and the establishment of positive 
learning contexts.

This brings me to a discussion of disruption and coming to speech.

\section{DISRUPTION AND COMING TO SPEECH: IN DEFENCE OF DEMOCRATIC EDUCATION}

Rancière (2006) challenges the insistence on current procedures of democratic education in particular in the book Hatred of Democracy, and offers a more positive way of thinking about democratic education, and consequently the democratic potential of educational technology espoused in this publication. The current procedures involve educators and students being grouped together and organised so that they engage with one another and listen and respond to one another's views in a critical manner. As a brilliant student of Louis Althusser in the 1960s, Rancière distanced himself radically from his teacher's work, specifically his different treatment of the concept of equality (Masschelein and Simons 2011, 150). For Althusser, equality is a promise or reward in the distant future that people have to aspire to attain through democratic education practices. By conceiving equality as yet to be achieved, the Althusserian view holds that a current inequality eventually has to be eradicated through democratic education practices (Masschelein and Simons 2011, 150). In this view, a distance is maintained between a present inequality and a distant equality, and consequently the poor (or worker) and rich (or boss) remain separated. Following such a view of democratic education, those students who are incapable of deliberating and those who can deliberate remain apart because the task of democratic education would be to ensure that deliberation is attained in future classroom interventions.

Rancière challenges the aforementioned view of equality and argues that equality is a claim to be made by all those who are considered as being "outside" the practice of democratic education (Rancière 2006, 18). In other words, democratic education does not mean that those considered as "outsiders" who make the claim of equality want to be included in democratic practices. Rather, as equals they "want to redefine the [democratic] order in such a way that new identities, new ways of doing and being become possible and can be counted” (Biesta 2009, 110). This implies that democratic education "is no longer a process of inclusion of excluded parties into the existing [democratic] order; it rather is a transformation of that order in the name of equality ... [and the] impetus for the transformation does not come from inside but from the outside” (Biesta 2009, 110). In a way, democratic education is about the power of those who have no or little power, those who are less qualified or less competent but who nevertheless intervene to install a momentary disruption and dissensus, that is, "they are intellectually equal in the very act of intervention and that they are competent in view of the 
common [democratic practice] from which they are nevertheless excluded" (Masschelein and Simons 2011, 155). And, for Rancière, “a dissensus is not a conflict of interests, opinions, or values; it is a division put in the common sense: a dispute about what is given, about the frame within which we see something as given ...” (Masschelein and Simons 2011, 156). Put differently, when "outsiders” intervene they verify their equality as beings that are able to speak and act. Equality refers to the assumption (and not the fact) that we all are able to (be qualified), and does not refer to the classic idea that we all have equal capacities, share particular qualifications or should have equal opportunities. Equality for Rancière, is always "intellectual equality and intellect or intelligence [and refers to] an ability to (speak, understand) ...” (Masschelein and Simons 2011, 165).

Therefore, assuming that everyone is equal implies assuming that everyone, regardless of their qualifications, "is able to"; for instance, every student is able to participate in deliberative moments and has the ability to disrupt such conversations through his or her ability to speak and understand. So, the hatred or fear of democracy refers to the hatred of those who are dominant and more eloquent who think they have a particular reason to govern and control a democratic practice. The dominant actually fear those who intervene in the name of equality, namely the less dominant, often marginalised, other. The importance of Rancière's work is that he thinks differently about democratic education and inclusion. For him, democratic education is sporadic in the sense that people from "outside", in other words less powerful or less democratic people, disrupt or interrupt the perceived democratic education practices in the name of equality. Therefore, students are not included in democratic education practices on the grounds that they are "outside” such practices and need to be included democratically. Rather, through deliberative discourses, using educational technology, students can play a role in interrupting the chain of reasons and consequences, causes and effects that shape their learning, as students are encouraged to create new forms of learning and to discover modes of action to make things happen (Masschelein and Simons 2011, 165). In Rancièrean terms, students have the equal ability to speak, to understand and to reshape an educational practice. The point about coming to speech in a disruptive way in terms of equality, is connected with embarking on educational research. In this article, the educational research that students and university teachers are committed to is action-oriented which means that through their actions of uncovering meanings and resolving problems teachers and students come to speech in a disruptive way. Their self-development, and articulation of voice are linked to the pursuit of problem-solving and hence, it can be claimed that their action research in educational practices are inextricably connected to the cultivation of equality. 


\section{CONCLUSION}

In this article, I discussed that action research encompasses problem solving, the pursuit of self-development and asserting one's voice. McNiff and Whitehead (2009, 12) confirm and extend on the aforementioned views, arguing the latter involving the discovery of new ways of improving learning as a means to improve personal and social circumstances. Additionally, it was conversed that action research comprises a rigorous process of observation (watching what is going on), reflection (thinking about whether it is good and why, and how it can be improved if necessary), monitoring and data gathering (keeping track of what you do and others do). It involves asking others to scrutinise your work, while you provide justification, and then rethink your work along the lines of constructive feedback. It may be surmised that the work of Deleuze and Guittari (1987, 16), can enhance learning through action research, as students and academics ascertain different "lines of flight" or deterritorialisations that rupture the striated or ordered ways of teaching and learning. These deterritorialisations may be facilitated through the creation of spaces, enabled through the use of educational technologies. As already mentioned, educational technologies support the creation of asynchronous learning environments towards what Garrison and Anderson (2003, xi) refer to as "explosive, unprecedented, amazing and disruptive” pedagogical opportunities for both students and educators. The creation of these pedagogical opportunities, through the use of educational technologies, may mitigate hierarchical teacher student interactions as described in Rancièrean terms, students have the equal ability to speak, to understand and to reshape an educational practice. Hence, it is not a question of equating educational technologies with the rhizome, but of thinking rhizomatically through the use of educational technologies (Conley 2009, 34).

\section{REFERENCES}

Alvermann, D. 2000. Researching libraries, literacies and lives: A rhizo-analysis. In Working the ruins: Feminist poststructural theory and methods in education, ed. E. St. Pierre, 118-132. New York: Routledge.

Biesta, G. 2009. Sporadic democracy: Education, democracy, and the question of inclusion. In Education, democracy, and the moral life, ed. M. Katz, S. Verducci and S. Biesta, 101-112. Washington: Springer.

Cochran-Smith, M. Goswami, D. and S. Lytle, S. 2009. Teacher research as stance. In The SAGE handbook of educational action research, ed. S. E. Noffke and B. Somekh, 39-49. Washington DC: SAGE.

Conley, V. A. 2009. Of rhizomes, smooth space, war machines and new media. In Deleuze and new technology, ed. M. Poster and D. Savat, 32-44. Edinburgh: Edinburgh University Press.

Deleuze, G. and F. Guittari. 1987. A thousand plateaus: Capitalism and schizophrenia. Translated by B. Massumi. Minneapolis, MN: University of Minnesota Press.

Elliott, J. 2009. Building educational theory through action research. In The SAGE handbook of educational action research, ed. S. E. Noffke and B. Somekh, 28-38. Washington DC: SAGE. 
Garrison, D. R. and T. Anderson. 2003. e-Learning in the $21^{\text {st }}$ century. London and New York: RoutledgeFalmer.

Honan, E. 2004. (Im)plausibilities: A rhizo-textual analysis of policy texts and teachers' work. Educational Philosophy and Theory 36(3): 267-281.

Kemmis, S. and R. McTaggert. 1990. The action research planner. Geelong: Deakan University.

Le Grange, L. 2011. Sustainability and higher education: From arborescent to rhizomatic thinking. Educational Philosophy and Theory 43(7): 742-754.

Masschelein, J. and M. Simons. 2011. The hatred of public schooling. In Rancière, public schooling and the taming of democracy, ed. J. Masschelein and M. Simons, 150-165. London: WileyBlackwell.

McHaney, R. 2011. The new digital shoreline: How Web 2.0 and Millennials are revolutionizing higher education. Sterling, VA: Stylus Publishing.

McKernan, J. 1991. Curriculum action research: A handbook of methods and resources for the reflective practitioner. London: Kogan Page.

McNiff, J. and J. Whitehead. 2006. All you need to know about action research. London: SAGE.

McNiff, J. and J. Whitehead. 2009. Doing and writing action research. London: SAGE.

Morss, J. 2000. The passional pedagogy of Gilles Deleuze. Educational Philosophy and Theory 32(2): $185-200$.

Noffke, S. E. 2009. Revisiting the professional, personal, and political dimensions of action research. In The SAGE handbook of educational action research, ed. S. E. Noffke and B. Somekh, 6-23. Washington DC: SAGE.

Rancière, J. 2006. Hatred of democracy. Translated by S. Corcoran. London and New York: Verso.

Sutton, D. 2008. Virtual structures of the Internet. In Deleuze reframed: A guide for the arts student, ed. D. Sutton and D. Martin-Jones, 27-42. London: Routledge. 